\title{
Investigation of wheat grits during storage
}

\author{
Zs. H. Horváth \\ B. P. Szabó \\ e-mail: horvatzs@mk.u-szeged.hu \\ e-mail: szpb@mk.u-szeged.hu
}

\author{
A. Véha \\ e-mail: veha@mk.u-szeged.hu \\ University of Szeged, Faculty of Engineering, \\ 6725 Moszkvai krt. 9., Szeged, Hungary
}

\begin{abstract}
The change of the quality of wheat milling products was investigated in our work. We analysed different types of wheat grists that are used in household (BL-55, BL-196, BFF-55 and AD). The grists were stored in three type of packages (paper bag, transparent PE bag, and woven PP bag) and in two different places (bright/warm and dark/cool place) for 6 months. The titre and colour characteristics of samples were measured monthly. Colour measurements were performed with a Hunter MiniScan colour-measuring instrument. The CIELab colour system was used for colour characterization. The values of titre were analysed using ANOVA. The type of package did not have significant influence on the titre. In the case of the BL-55, BL-196, and BFF-55 type of flours, the storage conditions had a significant effect on titre: it was smaller for samples that were stored in the dark/cool place. The value of titre rose significantly during storage for all samples.

To determine the change of colour, we calculated the $\Delta \mathrm{E}_{\mathrm{ab}}^{*}$ colour differences between colour coordinates measured at the beginning and during storage. The colour of the BL-55 and BL-196 flour samples did not change perceptibly. The variation of colour of the BFF-55 and AD type of flours was imperceptible for samples stored in the dark/cool place. The changing of the colour was well perceptible in the case of samples stored in the bright/warm place using paper bag or PP bag.
\end{abstract}

Keywords and phrases: wheat milling product, colour, storage, titre 


\section{Introduction}

Wheat grindings are one of the most important and most frequently used raw materials. As for every alimentary product, also for wheat grindings, the colour is an important parameter, which gives a primary image of it - especially for durum wheat pasta since it does not contain eggs. This explains the fact that instrumental colour measurements are applied on durum semolina also in industrial practice. In literature, various research results report on colour measurements of wheat grindings. Oliver et al. (1997) showed during the qualification in 1993 already that the ash content influences the colour of the flours. Further research on this topic by Horváth et al. (2004) proved that flours prepared from harder grain have lower $\mathrm{L}^{*}$ coordinate and higher $\mathrm{a}^{*}$ coordinate, and thus they are darker and have browner tone; besides that, the $\mathrm{L}^{*}$ lightness coordinate shows good correspondence with the whiteness index of the flours. Halászné et al. (1995) proposed a qualification system based on the colour measurements of durum semolina. D'egido \& Pagani (1997) compared the colour characteristics of pasta made of durum flour obtained by different grinding procedures. During the product manufacturing, the colour characteristics were mainly used to determine the appropriate roastedness (Hotti et al., 2000). Humphries et al. (2005) found a correlation between CIE b* and the lutein concentration of wheat. Konopka et al. (2004) established a relation between the colour characteristics of the flours and their lipid and colorant content. Gökmen \& Senyuva (2006) investigated the effect of heating on the colour parameters of wheat flour. László et al. (2008) examined the effects of ozone, UV, and combined ozone-UV treatment on the colour of wheat flour. Lamsal \& Faubion (2009) studied the effect of an enzyme preparation on wheat flour and dough colour, and pointed out that enzyme preparation did not improve lightness $\left(\mathrm{L}^{*}\right)$ and yellowness $\left(\mathrm{b}^{*}\right)$ of the flour system, but benzoyl peroxide sharply reduced $\mathrm{b}^{*}$.

The titre of wheat milling products is an important attribute, too. The high titre values of a wheat product cause failure in their quality. We investigated how the titre and colour characteristics of a wheat milling product change during storage.

\section{Materials and methods}

\subsection{Materials}

Different types of wheat milling products used in household were investigated: 
- BL-55 wheat flour;

- BL-196 whole wheat flour;

- BFF-55 pastry flour;

- AD semolina.

The samples were stored in three different types of packages:

- paper bag;

- transparent PE bag;

- woven PP bag.

The wheat products were stored in two different places, a bright/warm and a dark/cool place. The titre and colour coordinates of samples were measured monthly for 6 months.

\subsection{Measurement of titre}

Measurement of titre was performed according to MSZ 6369-11:1987 (Hungarian Standard Library). Suspension was made of $20 \mathrm{~g}$ flour and 200 cubic centimetre of water. This suspension was titrated to $\mathrm{pH} 8.4$ using $0.1 \mathrm{~mol} / \mathrm{l}$ $\mathrm{NaOH}$. The titre $(\mathrm{T})$ was calculated using the following formula:

$$
\mathrm{T}=\mathrm{L} / 2,
$$

where: $\mathrm{L}$ - the quantity of the used $0.1 \mathrm{~mol} / \mathrm{l} \mathrm{NaOH}$ in cubic centimetre.

\subsection{Measurement of colour}

Colour measurements were performed with a HunterLab MiniScan colourmeasuring instrument. The CIELab colour system was used for colour characterization. In this colour space, the colour points are characterized by three colour coordinates. $\mathrm{L}^{*}$ is the lightness coordinate ranging from no reflection for black $\left(L^{*}=0\right)$ to perfect diffuse reflection for white $\left(L^{*}=100\right)$. $a^{*}$ is the redness coordinate ranging from negative values for green to positive values for red. $\mathrm{b}^{*}$ is the yellowness coordinate ranging from negative values for blue and positive values for yellow.

The total colour change is given by the colour difference $\left(\Delta \mathrm{E}_{\mathrm{ab}}^{*}\right)$, in terms of the spatial distance between two colour points interpreted in the colour space (Hunter, 1987):

$$
\Delta \mathrm{E}_{\mathrm{ab}}^{*}\left[\left(\mathrm{~L}_{1}^{*}-\mathrm{L}_{2}^{*}\right)^{2}+\left(\mathrm{a}_{1}^{*}-\mathrm{a}_{2}^{*}\right)^{2}+\left(\mathrm{b}_{1}^{*}-\mathrm{b}_{2}^{*}\right)\right]^{1 / 2} .
$$


If $1.5<\Delta \mathrm{E}_{\mathrm{ab}}^{*}<3$, then the colour difference between samples can hardly be visually distinguished; if $\Delta \mathrm{E}_{\mathrm{ab}}^{*}>3$, then the colour difference between two samples can be visually distinguished.

The chroma $\left(\mathrm{C}_{\mathrm{ab}}^{*}\right)$ was used to determine the change of colour.

$$
\mathrm{C}_{\mathrm{ab}}^{*}\left(\left(\mathrm{a}^{*}\right)^{2}+\left(\mathrm{b}^{*}\right)^{2}\right)^{\frac{1}{2}} .
$$

The chroma represents colour saturation, which varies between dull at low chroma values and vivid colour at high chroma values (Hunter, 1987).

\section{Results}

\subsection{Variation of the titre of wheat milling products}

The values of titre were analysed using analysis of variance (ANOVA) (Rice, 1995). The Shapiro-Wilk test was used to control the conformance of data to the Gaussian distribution. The homogeneity of variances in the different groups was checked using Cochran test and Bartlett test. The results of ANOVA can be seen in Table 1 .

Table 1: Results of ANOVA for values of the titre

\begin{tabular}{|c|c|c|c|c|c|c|}
\hline \multirow{3}{*}{$\begin{array}{l}\text { Type of } \\
\text { milling } \\
\text { product }\end{array}$} & \multicolumn{6}{|c|}{ Factor } \\
\hline & \multicolumn{2}{|c|}{ Storage time } & \multicolumn{2}{|c|}{ Storage place } & \multicolumn{2}{|c|}{ Type of package } \\
\hline & $\begin{array}{c}\text { F- } \\
\text { value }\end{array}$ & $\begin{array}{c}\mathrm{p} \text { (level of } \\
\text { significance) }\end{array}$ & $\begin{array}{c}\text { F- } \\
\text { value }\end{array}$ & $\begin{array}{c}\mathrm{p} \text { (level of } \\
\text { significance) }\end{array}$ & $\begin{array}{c}\text { F- } \\
\text { value }\end{array}$ & $\begin{array}{c}\mathrm{p} \text { (level of } \\
\text { significance) }\end{array}$ \\
\hline BL 55 & 132.47 & 0.000 & 78.05 & 0.000 & 1.56 & 0.221 \\
\hline BL 196 & 97.47 & 0.000 & 54.24 & 0.000 & 0.36 & 0.691 \\
\hline BFF 55 & 37.46 & 0.000 & 12.63 & 0.001 & 1.25 & 0.302 \\
\hline $\mathrm{AD}$ & 59.72 & 0.000 & 0.02 & 0.876 & 2.92 & 0.073 \\
\hline
\end{tabular}

The results of ANOVA demonstrate that the titre of the milling product was significantly influenced by factor storage time $(\mathrm{p}<0,001)$, whereas the type of package did not influence the titre significantly. In the case of BL-55, BL-196, and BFF-55 types of flour, the storage conditions had significant effect on titre $(\mathrm{p}<0,001)$. The value of titre was smaller for samples stored in the dark/cool place.

Detailed analysis of changes in the averages of titre values measured during storage are presented with a confidence interval at a level of $95 \%$ in figures 1-4 for the different types of milling products. 
In Figure 1, we can see that the titre of BL55 type of wheat flour was dynamically increasing for two months, but after the rise it became slower.

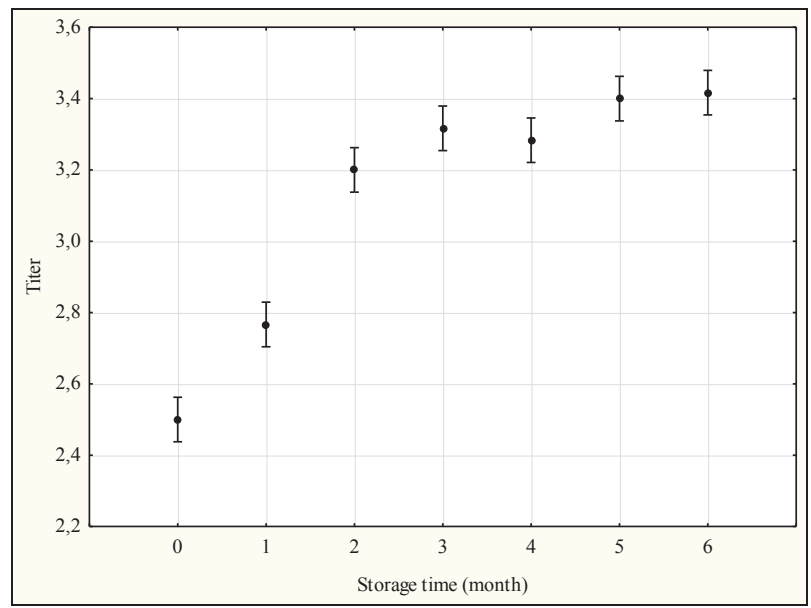

Figure 1: Results of ANOVA for titre in the case of the BL55 type of wheat milling product (average with confidence interval at a level of 95\%)

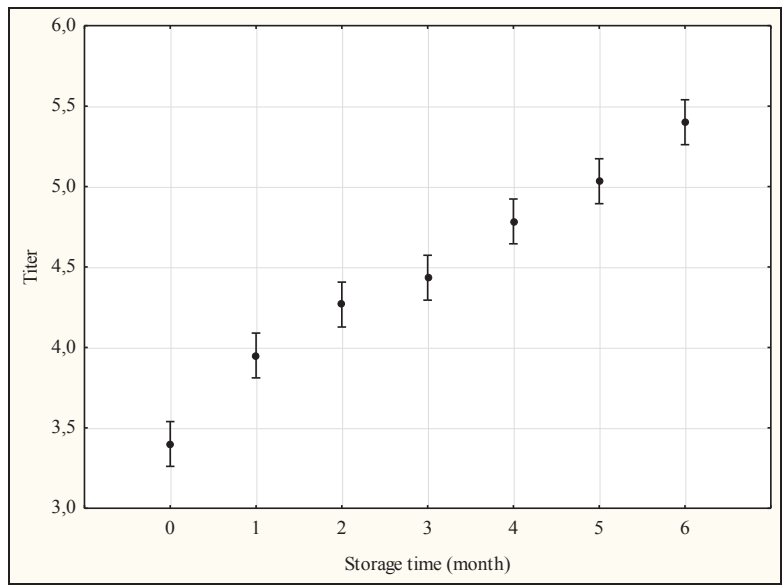

Figure 2: Results of ANOVA for titre in the case of the BL196 type of wheat milling product (average with confidence interval at a level of 95\%)

In the case of the BL196 flour, the titre increased permanently during storage, from 2.5 units to 5.4 units. In the case of the BFF 55 product, the titre 
increased permanently during storage too, from 2.1 units to 2.7 units. The titre of AD wheat milling product did not change significantly for four months, after which it rose powerfully, from 1.8 to 2.5 units.

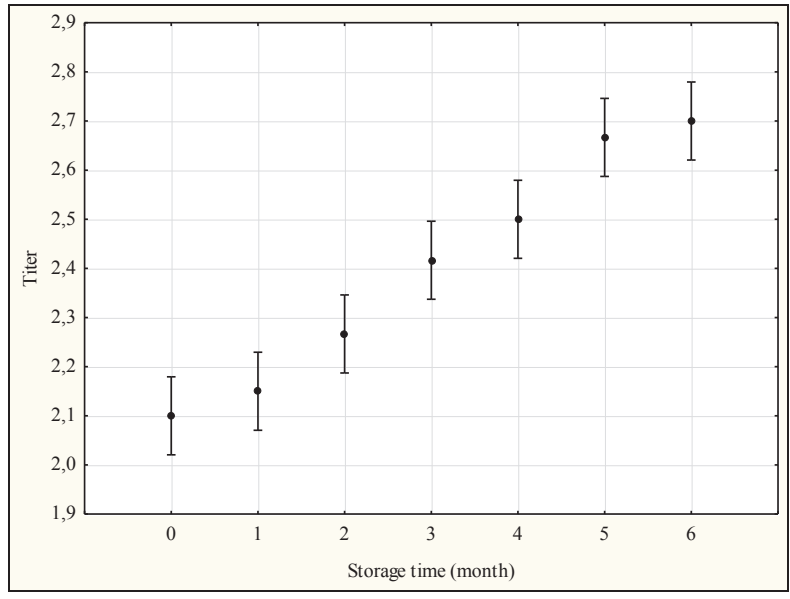

Figure 3: Results of ANOVA for titre in the case of the BFF55 type of wheat milling product (average with confidence interval at a level of 95\%)

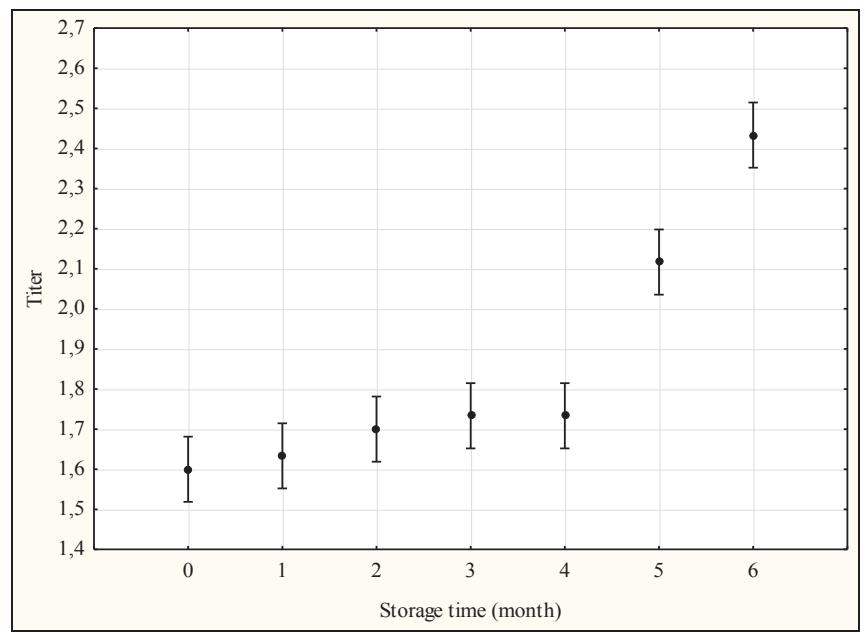

Figure 4: Results of ANOVA for titre in the case of the AD semolina type of wheat milling product (average with confidence interval at a level of 95\%) 


\subsection{Change of the colour of wheat milling products}

The colour differences of colour coordinates measured at the beginning and during storage were calculated to determine the changes in colour for all the different types of samples. The values are presented in Table 2. Colour difference values are usually higher in the case of samples stored in the bright/warm place, but values are higher than 3 units only for five samples.

Table 2: $\Delta \mathrm{E}_{\mathrm{ab}}^{*}$ colour differences calculated between colour coordinates measured at the beginning and during storage

\begin{tabular}{|c|c|c|c|c|c|c|c|c|}
\hline \multirow{3}{*}{$\begin{array}{l}\text { Type of } \\
\text { milling } \\
\text { product }\end{array}$} & \multirow{3}{*}{$\begin{array}{l}\text { Storage } \\
\text { place }\end{array}$} & \multirow{3}{*}{$\begin{array}{l}\text { Type of } \\
\text { package }\end{array}$} & \multicolumn{6}{|c|}{ Storage time (month) } \\
\hline & & & 1 & 2 & 3 & 4 & 5 & 6 \\
\hline & & & \multicolumn{6}{|c|}{$\Delta \mathrm{E}_{\mathrm{ab}}^{*}$ Colour difference } \\
\hline \multirow{6}{*}{ BL55 } & \multirow{3}{*}{ dark/cool } & paper bag & 0.45 & 0.36 & 0.65 & 1.24 & 0.64 & 0.88 \\
\hline & & PE bag & 0.43 & 0.37 & 0.24 & 1.04 & 0.75 & 0.87 \\
\hline & & PP bag & 0.39 & 0.34 & 0.62 & 0.93 & 0.52 & 1.07 \\
\hline & \multirow{3}{*}{ bright/warm } & paper bag & 0.20 & 0.62 & 1.21 & 1.05 & 1.43 & 1.51 \\
\hline & & PE bag & 0.39 & 0.31 & 0.48 & 1.07 & 0.57 & 1.14 \\
\hline & & PP bag & 1.09 & 0.69 & 1.21 & 1.40 & 1.15 & 1.80 \\
\hline \multirow{6}{*}{ BL196 } & \multirow{3}{*}{ dark/cool } & paper bag & 0.42 & 0.45 & 0.47 & 1.41 & 0.66 & 0.86 \\
\hline & & PE bag & 0.48 & 0.29 & 0.51 & 0.85 & 0.59 & 1.16 \\
\hline & & PP bag & 0.66 & 0.14 & 0.61 & 1.47 & 0.67 & 0.98 \\
\hline & \multirow{3}{*}{ bright/warm } & paper bag & 0.53 & 0.21 & 0.63 & 1.24 & 0.98 & 0.70 \\
\hline & & PE bag & 0.77 & 0.95 & 0.36 & 1.42 & 0.89 & 0.96 \\
\hline & & PP bag & 0.73 & 0.33 & 0.75 & 1.46 & 1.27 & 1.04 \\
\hline \multirow{6}{*}{ BFF55 } & \multirow{3}{*}{$\operatorname{dark} /$ cool } & paper bag & 0.81 & 0.73 & 0.72 & 1.01 & 0.86 & 1.37 \\
\hline & & PE bag & 0.84 & 0.66 & 0.66 & 0.75 & 0.65 & 1.01 \\
\hline & & PP bag & 0.85 & 0.64 & 0.74 & 1.33 & 0.93 & 1.36 \\
\hline & \multirow{3}{*}{ bright/warm } & paper bag & 0.81 & 1.42 & 2.38 & 1.66 & 2.76 & 3.63 \\
\hline & & PE bag & 0.77 & 0.49 & 0.51 & 1.18 & 0.66 & 1.44 \\
\hline & & PP bag & 0.78 & 1.08 & 1.79 & 1.69 & 2.63 & 3.59 \\
\hline \multirow{6}{*}{$\mathrm{AD}$} & \multirow{3}{*}{ dark/cool } & paper bag & 1.53 & 1.89 & 1.55 & 1.86 & 1.49 & 1.83 \\
\hline & & PE bag & 1.31 & 1.48 & 1.47 & 0.78 & 1.29 & 1.70 \\
\hline & & PP bag & 1.38 & 1.45 & 1.24 & 0.89 & 0.88 & 2.07 \\
\hline & \multirow{3}{*}{ bright/warm } & paper bag & 1.41 & 1.27 & 1.46 & 1.81 & 3.19 & 4.33 \\
\hline & & PE bag & 1.28 & 1.23 & 0.72 & 0.51 & 1.56 & 2.40 \\
\hline & & PP bag & 1.23 & 1.31 & 1.34 & 1.56 & 2.74 & 4.29 \\
\hline
\end{tabular}


The colour of BL-55 and BL-196 flour samples did not change perceptibly. The variation of colour of the BFF-55 and AD type of flours was imperceptible for samples stored in the dark/cool space.

The changing of the colour was well perceptible in the case of samples stored in the bright/warm place using paper bag or PP bag, after 5 or 6 months. The $\mathrm{C}^{*}$ ab chroma values of the initial samples and stored samples indicate that the colour of samples has become less saturated. In the case of the BFF-55 pastry flour, the chroma decreased from 8.37 units to 6.82 and 6.62 units; for $\mathrm{AD}$ semolina, the rise was from 7.73 units to 5.89 and 5.76 units.

To summarize, we can state the following:

The type of package did not influence the titre significantly. In the case of BL-55, BL-196, and BFF-55 types of flours, the storage conditions had a significant effect on titre: it was smaller for samples stored in the dark/cool place. The value of titre rose significantly during storage for all samples.

The colour of BL-55 and BL-196 flour samples did not change perceptibly during storage.

The variation of colour of the BFF-55 and AD type of flours was imperceptible for samples stored in the dark/cool space. The changing of the colour was well perceptible in the case of samples stored in the bright/ warm place, using paper bag or PP bag, after 5 or 6 months - the colour became less saturated.

\section{References}

[1] J. Oliver, A. Blakeney, H. Allen, The colour of flour streams related to ash and pigment contents. Journal of Cereal Science, 17. (1997) 169182.

[2] M. Halászné-Fekete, P. Záhonyiné-Racs, Á. Keleti, Colour measurement of durum grists for aim of qualification in paste industry. Book of the XXV $V^{\text {th }}$ Colouristic Symposium. (1995) 41-48.

[3] J. A. Rice, Mathematical statistics and data analysis, Duxbury Press (1995).

[4] M. D'Egidio, M. Pagani, Effect of the different stage of durum wheat chain on pasta colour. Italian Food \& Beverage Technology, 10. (1997) $17-20$. 
[5] A. S., Hotti, J. Sidhu, J. Al-Sager, Utililty of CIE tristimulus system in measuring the objective crumb colour of high-fibre toast bread formulation. Journal of Food Quality, 23. (2000) 103-116.

[6] Zs. Horváth, M. Fekete, A. Lakatos, Instrumental colour measuring for weathen grits. Cercetarea Ştiinţifică - o punte spre integrarea europeană. Simpozion cu participare internaţională. Arad, Analele, (2004) $83-88$.

[7] R. Hunter, The measurement of appearance, Wiley Press, New York. (1987).

[8] I. Konopka, W. Kozirok, D. Rotkiewicz, Lipids and carotenoids of wheat grain and flour and attempt of correlating them with digital image analysis of kernel surface and cross-sections. Food Research International, 37. (2004) 429-438.

[9] M. J. Humphries, R. D. Graham, D. J. Mares, Application of reflectance colour measurement to the estimation of carotene and lutein content in wheat and triticale. Journal of Cereal Science, 40. (2005) 151-159.

[10] V. Gökmen, H. Z. Senyuva, Study of colour and acrylamide formation in coffee, wheat flour and potato chips during heating. Food Chemistry, 99. (2006) 238-243.

[11] Zs. László, Zs. Hovorka-Horváth, S. Beszédes, Sz. Kertész, E. Gyimes, C. Hodúr, Comparison of the effects of ozone, UV and combined ozone/UV treatment on the colour and microbial counts of wheat flour. Ozone Science \& Engineering Journal, 30. (2008) 413-417.

[12] B. P. Lamsal, J. M. Faubion, Effect of an enzyme preparation on wheat flour and dough color, mixing, and test baking. Food Science and Technology, 42. (2009) 1461-1467.

[13] MSZ 6369-11:1987: Flour test methods. Determination of $\mathrm{pH}$ acidity degree and fat acidity. (Lisztvizsgálati módszerek. A pH, a savfok és a zsírsavszám meghatározása). Hungarian Standard Library: szabvanykonyvtar.mszt.hu. 